\title{
FGF Gene Amplification
}

National Cancer Institute

\section{Source}

National Cancer Institute. FGF Gene Amplification. NCI Thesaurus. Code C118376.

A molecular genetic abnormality indicating the presence of multiple copies of an FGF family gene. 